\title{
PENINGKATAN AKTIVITAS PEMBELAJARAN LOMPAT JAUH DENGAN METODE DISTRIBUTED PROGRESSIVE
}

\author{
Suko Pambudi \\ UPTD SMP Negeri 1 Ngadiluwih Kabupaten Kediri \\ sukopambudi63@gmail.com
}

\begin{abstract}
Abstrak
Penelitian ini adalah meningkatkan pembelajaran lompat jauh siswa kelas IX UPTD SMPN 1 Ngadiluwih Kabupaten Kediri pada pelajaran Pendidikan Jasmani, Olahraga, dan Kesehatan menggunakan metode Distributed Progressive semester ganjil tahun pelajaran 2015/2016. Metode Distributed Progressive merupakan bentuk latihan bertahap yang yang diselingi istirahat diantara tahapan latihan. Program latihan progresif terdistribusi (Distributed Progressive) dapat membuat para pelatih atau guru untuk lebih mengkhususkan program latihan yang lebih teliti bagi setiap siswa atau atlet. Hipotesis tindakan pada penelitian ini, yaitu meningkatnya pembelajaran lompat jauh pada siswa kelas IX UPTD SMPN 1 Ngadiluwih Kabupaten Kediri tahun pelajaran 2015/2016 pada pelajaran Pendidikan Jasmani, Olahraga, dan Kesehatan dengan menggunakan metode Distributed Progressive. Penelitian ini diawali dengan memantau keterlibatan siswa dalam proses pembelajaran. Kemudian dilanjutkan dengan mencari model pembelajaran yang tepat agar mampu mengatasi permasalahan tersebut. Maka, Distributed Progressive merupakan metode tepat guna untuk meningkatkan hasil lompat jauh siswa kelas IX di UPTD SMPN 1 Ngadiluwih Kabupaten Kediri.
\end{abstract}

Kata kunci: lompat jauh, distributed progressive, penelitian tindakan kelas.

\section{PENDAHULUAN}

Pendidikan Jasmani dan Kesehatan yang selanjutnya disebut penjaskes merupakan salah satu mata pelajaran yang digemari siswa. Penjaskes dianggap sebagai sarana bermain, karena pembelajaran lebih banyak dilakukan di luar kelas. Oleh sebab itu, mata pelajaran ini memiliki panduan pelajaran sendiri yang harus diajarkan, dimiliki, dan dipahami siswa. Materi penjaskes berbeda dengan materi pembelajaran lain, karena selain memahamkan berbagai teori, para siswa juga harus memahami praktik berupa aktivitas jasmani atau olahraga yang disesuaikan dengan kemampuan dan karakterisitik masing-masing. Sebagai pihak yang memiliki peran besar dalam kesegaran jasmani siswa, Guru penjaskes harus dapat menciptakan, mendorong, serta mengelola situasi pembelajaran dengan kemampuan yang dimiliki. Tujuannya agar pembelajaran dapat terlaksana dengan baik.

Dalam proses pembelajaran di lapangan tidak menutup 
kemungkinan terjadi kendala atau permasalahan. Hal tersebut juga terjadi dalam pembelajaran penjaskes di UPTD SMPN 1 Ngadiluwih Kabupaten Kediri. Kendala terjadi pada mata pelajaran materi lompat jauh, di mana banyak siswa takut melakukan lompat jauh. Akibatnya pada saat test unjuk kerja, banyak siswa yang gagal. Penyebabnya, pelajaran lompat jauh adalah pelajaran yang dianggap sulit oleh siswa, karena ada beberapa teori pelajaran yang harus dikuasai sekaligus, seperti sikap awalan, sikap tolakan, sikap saat melayang, dan sikap pendaratan Sunaryo (1979: 95-99).

Nomor lompat jauh merupakan bagian dari cabang atletik. Nomor lompat jauh berupa melompat di atas papan tolakan untuk menghasilkan lompatan yang jauh. Menurut Saputra (2001: 63) gerakan melompat merupakan salah satu bentuk gerak lokomotor. Dalam proses evaluasi lompat jauh hal yang utamakan adalah proses gerakan dari siswa. Menurut Simanjuntak (2008: 13), pengembangan instrumen evaluasi dalam pendidikan jasmani dilakukan dengan mengacu pada perkembangan gerak siswa seperti yang diuraikan dalam kurikulum.

Oleh sebab itu, peneliti menganggap perlu dilakukannya sebuah penelitian untuk meningkatkan kemampuan siswa
UPTD SMPN 1 Ngadiluwih dalam pelajaran lompat jauh. Berdasarkan hal tersebut, maka dalam proses pembelajaran lompat jauh peneliti menggunakan metode yang dapat menciptakan suasana pembelajaran menjadi lebih santai dan tidak monoton. Metode pembelajaran tersebut adalah Distributed Progressive. Metode latihan progresif terdistribusi (Distributed Progressive) merupakan bentuk latihan bertahap yang yang diselingi istirahat diantara tahapan latihan. Program latihan progresif terdistribusi (Distributed Progressive) dapat membuat para pelatih atau guru untuk lebih mengkhususkan program latihan yang lebih teliti bagi setiap siswa atau atlet. Program latihan distributed progresif pelaksanaan tindakannya hari ke hari sehingga siswa bisa mengamati kemajuannnya.

Menurut Samsudin (2008: 44) dua ciri dari metode progresif ini adalah: (1) dalam susunan tahapan pembelajaran, tahap berikutnya selalu memuat gerakan yang dilatih di tahap sebelumnya, misalnya tahap satu selalu ada tahap dua, tahap dua dan tahap dua selalu ada tahap tiga, tahap satu, dua, dan tiga, selalu ada ditahap empat, begitu seterusnya; dan (2) Gerakan yang dijadikan inti atau dianggap penting dalam keterampilan yang dipelajari, selalu muncul dan mendapat penekanan pada setiap pembelajaran. 
Berdasarkan uraian di atas, peneliti akan melakukan penelitian tindakan kelas dengan tujuan meningkatkan pembelajaran lompat jauh siswa kelas IX IUPTD SMPN 1 Ngadiluwih Kabupaten Kediri pada pelajaran Pendidikan Jasmani, Olahraga, dan Kesehatan menggunakan metode Distributed Progressive semester ganjil tahun pelajaran 2015/2016. Harapan dari penelitian tersebut agar dapat bermanfaat untuk pengembangan teori pembelajaran pendidikan jasmani pada umumnya dan penggunaan metode Distributed Progressive dalam pembelajaran lompat jauh pada khususnya.

\section{METODE PENELITIAN}

Penelitian ini merupakan penelitian tindakan kelas atau Classroom Action Research. Penelitian Tindakan Kelas merupakan suatu bentuk penelitian yang berbentuk reflektif dengan melakukan tindakan tertentu untuk memperbaiki dan meningkatkan praktik pembelajaran di kelas secara lebih berkualitas sehingga siswa dapat memperoleh hasil belajar yang lebih baik (Asrori, 2008).

Penelitian ini dilaksanakan di UPTD $\quad$ SMPN 1 Ngadiluwih Kabupaten Kediri. Penelitian ini dilakukan pada bulan Agustus hingga Septembersemester ganjil tahun pelajaran 2015/2016. Subjek penelitian adalah siswa kelas IX IUPTD SMPN 1 Ngadiluwih Kabupaten Kediri tahun pelajaran 2015/2016 yang berjumlah 40. Sebagai objek dalam penelitian ini adalah mata pelajaran Pendidikan Jasmani, Olahraga, dan Kesehatan pada pembelajaran lompat jauh.

Penelitian ini diawali dengan memantau keterlibatan siswa dalam proses pembelajaran. Dilanjutkan dengan mencari model pembelajaran yang tepat agar mampu mengatasi permasalahan tersebut Penelitian ini menggunakan model spiral dari Kemmis dan Taggart yang dikembangkan oleh Stephen Kemmis dan Robbin Mc Taggart. Tujuan menggunakan desain penelitian model ini adalah apabila dalam pelaksanaan tindakan ditemukan adanya kekurangan, maka perencanaan dan pelaksanaan tindakan perbaikan masih dapat dilanjutkan pada siklus berikutnya sampai target yang diinginkan tercapai.

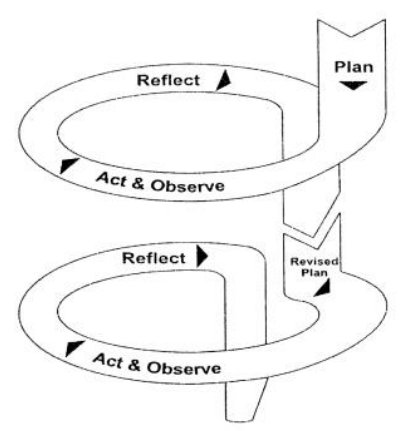

Model Spiral dari Kemmis dan Mc Taggart (Pardjono dkk, 2007:22)

Prosedur penelitian meliputi perencanaan, tindakan, observasi, dan refleksi. Penelitian tindakan ini akan 
dilaksanakan dalam dua siklus. Setiap siklus memuat tindakan yang meliputi perencanaan, tindakan, observasi, dan refleksi. Satu siklus penelitian dilakukan dalam tiga kali pertemuan.

\section{PEMBAHASAN}

\section{Siklus 1}

Peneliti membuat RPP dengan metode Distributed Progressive yang digunakan sebagai pedoman pelaksanaan kegiatan pembelajaran. Hal kedua yang dilakukan, yaitu merencanakan gerakan-gerakan yang berkaitan dengan materi pelajaran yang akan diberikan kepada siswa. Hal ketiga, peneliti menyusun dan mempersiapkan lembar observasi siswa mengenai proses pembelajaran. Pengamatan dilihat dari aspek guru dan siswa. Hal terakhir, yaitu mempersiapkan sarana dan media pembelajaran yang akan digunakan dalam proses pembelajaran.

Pada pelaksanaan peneliti menjelaskan secara singkat untuk memberikan pengetahuan umum kepada siswa. Guru bertanya jawab sekilas mengenai cabang olahraga lompat jauh. Siswa mendengarkan dengan baik. Berikutnya, peneliti mengajak siswa melakukan gerakan awalan. Lari secepatnya tanpa mengubah langkah, kecepatan lari semakin cepat sebelum melakukan tolakan. Sesuai sintaks dari metode Distributed Progressive, pemberian materi diselingi dengan istirahat dan dilanjutkan latihan kembali. Langkah selanjutnya, dilanjutkan gerakan tolakan, guru mengajak siswa melakukan gerakan tolakan.

Berikutnya, peneliti siswa melakukan gerakan melayang. Setelah melayang, mengangkat kaki kanan ke depan. Kedua kaki segera dikayuh menyerupai orang naik sepeda. Posisi badan agak condong. Posisi lengan di atas badan seperti orang mengayuh. Lakukan persiapan pendaratan. Terakhir, siswa melakukan gerakan mendarat. Kedua kaki diluruskan ke depan. Kedua lengan diluruskan ke depan. Pertahankan keseimbangan badan. Mendarat dengan kedua kaki bersamaan. Kedua lutut ditekuk agar dapat seimbang saat mendarat. Badan agak condong ke depan.

Nilai hasil tes siswa siklus I adalah nilai yang didapat dari tes keterampilan melakukan gerakan dasar dalam lompat jauh di akhir siklus I. Nilai kriteria ketuntasan minimal (KKM) yang ditetapkan di pelajaran Pendidikan Jasmani, Olahraga, dan Kesehatan kelas IX UPTD SMPN 1 Ngadiluwih Kabupaten Kediri adalah 75. Berdasarkan data, maka terlihat 50\% (20) siswa yang memiliki nilai tuntas KKM di tahap siklus I. Dengan ratarata nilai siswa di siklus I adalah 71,4 atau di bawah nilai KKM. 
Berdasarkan hasil dari siklus I tersebut, maka perlu mempersiapkan lebih baik lagi pada siklus II, agar KKM dapat meningkat dan sesuai dengan yang diharapkan. Selain itu, pada siklus 2, peneliti memperhatikan saran-saran yang didapat dari observer.

\section{Siklus 2}

Pada proses awal peneliti membuat RPP dengan metode Distributed Progressive yang telah direvisi sesuai saran observer dari siklus I. Berikutnya peneliti mempersiapkan gerakan-gerakan lompat jauh yang diberikan kepada siswa. Langkah selanjutnya, peneliti menyusun dan mempersiapkan lembar observasi siswa mengenai proses pembelajaran. Pengamatan dilihat dari aspek guru dan siswa. Terakhir, peneliti mempersiapkan sarana dan media pembelajaran yang akan digunakan dalam proses pembelajaran.

Pada kegiatan ini, peneliti menjelaskan secara singkat untuk memberikan pengetahuan umum kepada siswa. Peneliti mengingatkan siswa untuk mengingat kembali teknik yang telah diajarkan pada siklus sebelumnya. Langkah selanjutnya, peneliti membentuk siswa ke dalam kelompok beranggota 10 siswa, sehingga ada 4 kelompok besar. Hal ini berdasarkan saran observer pada siklus I. Observer menganggap dengan membentuk kelompok maka akan lebih mudah dalam mengajari teknik. Peneliti tidak perlu membenarkan satu persatu siswa yang salah. Cukup diserahkan pada anggota kelompoknya untuk saling mengajari teman.

Berikutnya, peneliti mengajak siswa melakukan gerakan awalan, yaitu siswa lari secepatnya tanpa mengubah langkah, kecepatan lari semakin cepat sebelum melakukan tolakan. Selanjutnya, peneliti mempersilakan siswa istirahat sejenak sambil mengingat gerakan yang diajarkan sebelumnya. Sambil istirahat guru meminta siswa untuk berlatih gerakan yang diajarkan dan saling membantu temannya yang belum bisa. Hal ini berdasarkan saran oberver pada siklus I.

Langkah

berikutnya, dilanjutkan gerakan tolakan, peneliti mengajak siswa melakukan gerakan tolakan. Tolakan dilakukan pada salah satu kaki yang terkuat. Kaki tepat pada papan tolak. Ayunkan paha lurus ke depan. Luruskan kaki, lutut, dan pinggang pada waktu melakukan tolakan. Tolakkan kaki sekuatnya ke depan atas Sudut tolakan 45 derajat. Latihan dilanjutkan dengan pemberian materi tolakan. Sebelumnya guru memberikan gerakan yang tepat dilanjutkan dengan siswa. 
Selanjutnya dilanjutkan gerakan melayang, peneliti mengajak siswa melakukan gerakan melayang. Pada gerakan melayang, peneliti mengarahkan siswa agar mengangkat kaki kanan ke depan. Kedua kaki segera dikayuh menyerupai orang naik sepeda. Posisi badan agak condong. Posisi lengan di atas badan seperti orang mengayuh. Kemudian melakukan persiapan pendaratan. Materi dilanjutkan dengan gerakan ketika melayang di udara. Gerakan ini sangat penting karena menentukan jarak lompatan. Peneliti meminta siswa perkelompok satu persatu untuk melakukan gerakan melayang ini.

Berikutnya dilanjutkan gerakan mendarat, peneliti mengajak siswa melakukan gerakan mendarat. Peneliti memberikan arahan agar kaki diluruskan ke depan. Kedua lengan diluruskan ke depan. Pertahankan keseimbangan badan. Mendaratlah dengan kedua kaki bersamaan. Kedua lutut ditekuk agar dapat mengeper saat mendarat. Badan agak condong ke depan. Jaga keseimbangan badan agar badan tidak jatuh ke belakang.

Setiap siswa secara urut diminta melakukan lompat jauh. Kegiatan harus diawali dari gerakan awalan, tolakan, melayang dan mendarat. Guru menilai praktik siswa. Siswa diberi kesempatan dua kali untuk melakukan lompat jauh.
Terakhir, peneliti mengevaluasi kegiatan lompat jauh yang dilakukan siswa. Pada siklus ini kondisi siswa nampak semangat dalam mengikuti aktivitas lompat jauh. Namun masih terdapat siswa yang belum benar dalam melakukan teknik lompat jauh.

Hasil dari evaluasi siklus 2, di antaranya: 1) masih ada siswa yang belum bisa melakukan teknik dengan tepat; 2) ada siswa yang bercanda, sehingga tidak maksimal; 3) waktu istirahat terlalu lama, sehingga menyita waktu. Nilai hasil tes siswa siklus II adalah nilai yang didapat dari tes keterampilan melakukan gerakan dasar dalam lompat jauh di akhir siklus II.

Nilai kriteria ketuntasan minimal (KKM) yang ditetapkan di pelajaran Pendidikan Jasmani, Olahraga, dan Kesehatan kelas IX UPTD SMPN 1 Ngadiluwih Kabupaten Kediri adalah 75. Berdasarkan data, maka terlihat $80 \%$ (32) siswa yang memiliki nilai tuntas KKM di tahap siklus II. Dengan ratarata nilai siswa di siklus II adalah 77,8atau di atas nilai KKM.

Perilaku siswa dalam setiap siklus terus diamati oleh observer untuk melihat secara fisik tentang perkembangan yang terjadi. Hasil keseluruhan observasi terhadap siswa dapat dilihat pada tabel berikut. 
Data observasi terhadap siswa di siklus I dan siklus II

\begin{tabular}{|c|l|c|c|}
\hline \multirow{2}{*}{ Aspek Pengamatan } & \multicolumn{1}{|c|}{ Uraian Aspek Pengamatan } & Siklus I & Siklus II \\
\hline \multirow{4}{*}{ Verbal } & Siswa bertanya & $<6$ & $11-15$ \\
\cline { 2 - 4 } & Siswa mengobrol sendiri di luar materi & $6-10$ & $<6$ \\
\cline { 2 - 4 } & Siswa dapat menjawab pertanyaan guru & $6-10$ & $11-15$ \\
\cline { 2 - 4 } & Siswa bercanda & $11-15$ & $<6$ \\
\hline \multirow{5}{*}{ Non-verbal } & Siswa antusias belajar & $11-15$ & $>15$ \\
\cline { 2 - 4 } & Siswa percaya diri & $6-10$ & $>15$ \\
\cline { 2 - 4 } & Siswa malu & $11-15$ & $<6$ \\
\cline { 2 - 4 } & Siswa bermain-main sendiri & $<6$ & 0 \\
\cline { 2 - 4 } & Siswa menyimak guru & $11-15$ & $>15$ \\
\cline { 2 - 4 } & Siswa terlibat aktif & $>15$ & $>15$ \\
\cline { 2 - 4 } & Siswa menghargai hasil kerja teman & & \\
\hline
\end{tabular}

Data pada tabel di atas memperlihatkan hasil observasi yang dilakukan observer terhadap perilaku siswa di kelas saat PTK dilaksanakan. Pada tabel di atas terdapat beberapa aspek penilaian yang terbagi dalam aspek negatif dan positif. Terjadi peningkatan pada aspek positif siswa bertanya, siswa dapat menjawab pertanyaan guru, dan siswa percaya diri. Hal ini memperlihatkan bahwa pada siklus penelitian yang dilakukan dapat meningkatkan jumlah siswa yang melakukan aspek positif. Terjadi penurunan pada aspek negatif peserta mengobrol sendiri, siswa bercanda, siswa malu, dan siswa bermain-main sendiri. Hal ini memperlihatkan bahwa pada siklus penelitian yang dilakukan dapat menurunkan jumlah siswa yang melakukan aspek negatif. Hal ini terjadi karena semua siswa telah menyimak guru dengan baik dalam pembelajaran menurut pandangan observer.

Untuk mengetahui persentase ketercapaian KKM siswa di setiap siklus, rumus yang digunakan adalah frekuensi siswa tuntas KKM/ jumlah siswa x 100\%. Telah diketahui bahwa jumlah siswa kelas IX UPTD SMPN 1 Ngadiluwih Kabupaten Kediri tahun pelajaran 2015/2016 adalah 40 orang.

KKM siswa setiap siklus dan persentasenya

\begin{tabular}{|l|c|c|}
\hline \multicolumn{1}{|c|}{ Keterangan } & Siklus I & Siklus II \\
\hline $\begin{array}{l}\text { Jumlah siswa lolos } \\
\text { KKM }\end{array}$ & 20 & 32 \\
\hline$\%$ siswa lolos KKM & $50 \%$ & $80 \%$ \\
\hline Rata-rata nilai siswa & 71,4 & 77,8 \\
\hline
\end{tabular}

Data pada tabel dia atas memperlihatkan kenaikan jumlah siswa yang mencapai ketuntasan minimal di setiap siklus. Indikator keberhasilan dari penelitian ini adalah terdapat $75 \%$ siswa yang lolos KKM. Berdasarkan data pada tabel 13 terlihat 
bahwa siklus I terdapat 50\% (20) siswa tuntas KKM. Kemudian, pada siklus II terdapat $80 \%$ (32) siswa tuntas KKM. Data tersebut memperlihatkan terjadi peningkatan dari siklus I sampai siklus II. Keberhasilan penelitian sesuai dengan indikator keberhasilan didapat saat siklus II, yaitu $80 \%$ siswa tuntas KKM atau lebih dari 75\% siswa tuntas KKM.

Nilai rata-rata unjuk kerja siswa di setiap siklus mengalami kenaikan.. Pada siklus I nilai rata-rata siswa adalah 71,4 atau di atas nilai KKM. Pada siklus II nilai rata-rata siswa meningkat menjadi 77,8 atau di atas KKM. Dapat disimpulkan bahwa penggunaan metode Distributed Progressiveberhasil meningkatkan hasil pembelajaran lompat jauhIX I di UPTD $\quad$ SMPN 1 Ngadiluwih Kabupaten Kediri tahun pelajaran 2015/2016.

\section{SIMPULAN}

Penerapan metode
Distributed Progressive pada siswa siswa kelas IX di pelajaran Pendidikan Jasmani, Olahraga, dan Kesehatan tahun pelajaran 2015/2016 berjalan dalam dua siklus penelitian. Setiap siklus penelitian terdiri atas tiga kali pertemuan. Setiap pertemuan terdiri atas 2 jam pelajaran (4 x 40 menit).

Upaya yang dapat dilakukan oleh guru untuk medongkrak pembelajaran lompat jauh adalah menggunakan metode Distributed Progressive. Penerapan metode ini dimulai dari guru memberikan penjelasan materi diselingi dengan istirahat. Pada tahap pertama guru membentuk siswa dalm kelompok, kemudian mencontohkan gerakan awalan dan meminta siswa mempraktikannya. Kemudian siswa dipersilahkan untuk istirahat. Ketika istirahat siswa dapat berlatih dan saling membantu teman mereka. Kemudian dilanjutkan dengan materi tolakan dan siswa mempraktikkannya. Setelah selesai siswa dapat istirahat dan dilanjutkan materi melayang. Setelah selesai dilanjutkan istirahat dan siswa diminta melanjutkan dengan kegiatan lompat jauh yang mengikuti teknik awalan, tolakan, melayang, dan mendarat.

Indikator keberhasilan pada penelitian ini dilihat dari $75 \%$ siswa tuntas KKM (dengan nilai 75). Hasil penelitian yang didapat dari data tes memperlihatkan bahwa pada siklus I terdapat 50\% (20) siswa tuntas KKM. Kemudian, pada siklus II terdapat 80\% (32) siswa tuntas KKM. Keberhasilan penelitian sesuai dengan indikator keberhasilan didapat saat siklus II, yaitu $80 \%$ siswa tuntas KKM atau lebih dari $75 \%$ siswa tuntas KKM. Dengan demikian dapat disimpulkan bahwa penggunaan metode Distributed Progressive berhasil meningkatkan pembelajaran lompat jauhsiswa kelas 
IX UPTD SMPN 1 Ngadiluwih

Kabupaten Kediri pada pelajaran Pendidikan Jasmani, Olahraga, dan Kesehatan tahun pelajaran 2015/2.

\section{DAFTAR PUSTAKA}

Asrori, Muhammad. 2009. Penelitian Tindakan Kelas. Bandung: CV Wacana Prima.

Samsudin, 2008. Pembelajaran pendidikan Jasmani Olahraga dan Kesehatan. Jakarta: Prenada Media Group.
Saputra, Yudha M. 2004. Pembelajaran Atletik di Sekolah Dasar (Sebuah Pendekatan Pembinaan Gerak Dasar Melalui Permainan). Jakarta: Depdiknas.

Simanjuntak, Victor G, dkk. 2008. Pendidikan Jasmani dan Kesehatan. Jakarta: Depdiknas.

Sunaryo. 1979. Pedoman Atletik. Jakarta: Kemendibud. 